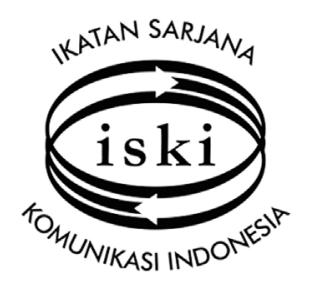

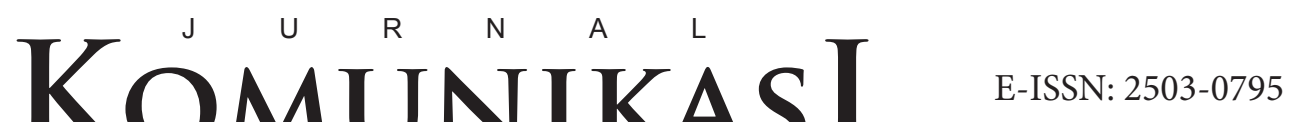 \\ P-ISSN: 2548-8740
}

\section{Journalist as Professional versus Employee - a Case of Daily Koran Sindo in Censoring News on Trump's Travel-Ban Policy}

\author{
http://dx.doi.org/10.25008/jkiski.v2i2.106 \\ Tjipta Lesmana \\ School of Postgraduate Communication Science \\ Budi Luhur University \\ Jl. Ciledug Raya, Petukangan Utara, Jakarta 12260 - Indonesia \\ tjipta.lesmana@budiluhur.ac.id
}

\begin{abstract}
Freedom of the press worldwide faces serious threat from owners of the media. Theoretically, journalist is independent and able to write whatever he or she wants to print. News is anything that fits to print, the jargon out cried in early years of Libertarian Media Theory. It is the journalist who has the power to give criteria for "fitting" to print. Now the jargon has changed drastically: "He who pays the piper calls the tune". Newsroom is nowadays not beyond owner's intervention. Owners run news media for specific reason. If they decide that a commentary or a news report goes against their beliefs or their interests or if they consider them biased, they certainly will want to intervene. The case of daily Koran Sindo is interesting to be investigated. While most media in the world, including those in Indonesia, heavily exposed President Donald Trump's controversial policy in banning people from seven middle-east and African countries from entering the US, daily Koran Sindo totally blocked the news. Not any single news criticizing Trump's policy is printed at the paper owned by Hary Tanoesudibjo. How the daily "plays the game" the author makes a simple research using qualitative content analysis. .
\end{abstract}

Key words: Freedom of the Press, Media Ownership, Travel-ban Policy, Terrorism.

\begin{abstract}
Abstrak
Kebebasan pers menghadapi ancaman dari pemilik media di Indonesia. Secara teoritis, wartawan memiliki kebebasan untuk menulis dan mempublikasikan apa saja yang dikehendaknya. "News ia anything that fits to print", begitu jargon yang populer di kalangan penganut teori pers libertarian. Kriteria "layak dipublikasilan", sepertinya, berada di tangan wartawan. Namun, jargon itu kini berubah drastis. "He who pays the piper calls the tune", mereka yang memiliki uang (pemilik) yang menentukan layak-tidaknya berita untuk dipublikasikan. Pemodal mempunyai tujuan tertentu untuk masuk ke bisnis media. Jika dia menilai suatu berita tidak sejalan dengan pandangannya, atau bertentangan dengan kepentingan bisnisnya, dia akan melakukan intervensi di meja redaksi. Kasus harian Koran Sindo menarik untuk diteliti, terkait dengan Perintah Eksekutif Presiden Donald Trump yang melarang masuk ke Amerika penduduk dari tujuh negara mayoritas Islam di Timur Tengah dan Afrika. Semua media di manca-negara, termasuk di Indonesia, menaruh perhatian khusus, bahkan mengecamnya. Hanya Koran Sindo yang tidak memuat berita tersebut. Tidak ada satu pun berita tentang kebijakan anti-imigran Trump yang dipublikasikan Koran Sindo selama 31 Januari 2017 hingga 7 Februari 2017. Dengan sengaja rubrik "Internasional" Koran Sindo mengalihkan perhatian pembacanya pada berita-berita lain yang sebenarnya mengandung nilai berita rendah. Tampaknya, kebijakan Redaksi Koran Sindo tentang kasus Trump itu terjadi atas perintah pemilik, Hary Tanoesudibdjo, karena Hary punya hubungan pribadi yang dekat, bahkan hubungan bisnis dengan Donald Trump.
\end{abstract}

Kata kunci: Freedom of the Press, Media Ownership, Travel-ban Policy, Terrorism. 


\section{Introduction}

On January 27, 2017 President Donald Trump issued an Executive Order -later known as anti-immigrant or travel ban policy. In its First paragraph The Order said:

[...] By the authority vested in me as President by the Constitution and laws of the United States of America, including the Immigration and Nationality Act (INA), 8 U.S.C. 1101 et seq., and section 301 of title 3, United States Code, and to protect the American people from terrorist attacks by foreign nationals admitted to the United States, it is hereby ordered as follows: Section 1. Purpose. The visaissuance process plays a crucial role in detecting individuals with terrorist ties and stopping them from entering the United States. Perhaps in no instance was that more apparent than the terrorist attacks of September 11, 2001, when State Department policy prevented consular officers from properly scrutinizing the visa applications of several of the 19 foreign nationals who went on to murder nearly 3,000 Americans. And while the visa-issuance process was reviewed and amended after the September 11 attacks to better detect would-be terrorists from receiving visas, these measures did not stop attacks by foreign nationals who were admitted to the United States.

The Executive Order, in fact, does not explicitly name the seven countries with their population ban to enter the US. They were all singled out as exceptional security risks in the Terrorist Prevention Act of 2015 and its 2016 extension. It merely refers to the sections of U.S. Code that were changed by the Terrorist Prevention Act. A different section of the Executive Order does refer to Syria specifically, because it calls for the indefinite suspension of Syrian refugee admissions, until such time as the President believes security concerns have been adequately addressed. The list of the seven nations affected by Trump's executive order was, factually, compiled by President Barack Obama's Department of Homeland Security, in a series of judgments that actually goes back to Obama's first term, circa 2011. Barack Obama made this list, not Donald Trump, and there was very little resistance from congressional Democrats at any step in the process of arriving at the final list of Iraq, Iran, Syria, Libya, Somalia, Sudan, and Yemen.

Since its issuance on January 27, 2017 President Trump's Executive Order elicits worldwide uproar and criticism. The Telegraph, a popular daily from Britain, wrote in its February 8, 2017 edition "The decision had unleashed chaos at airports in America and around the worlds, as thousands - including green card holders - found themselves banned from boarding their planes or detained on arrival." Opponents of Trump's policy, according to The Telegraph, accused White House Executive Oder was intentionally discriminatory against Moslems.

On its February 1, 2017 edition the New York Times wrote, "The executive order on immigration that Mr. Trump signed on Friday might be viewed as the first major victory for this geopolitical school. And a second action, which would designate the Moslem Brotherhood, the Islamist political movement in the Middle East, as a terrorist organization, is now under discussion at the White House, administration officials say." The New York Times is of the opinion that Trump's Executive Order has stamped dark view of Islam. "It declared that the United States should keep out those with 'hostile attitudes toward it and its founding principles' and 'those who would place violent ideologies over American law,' clearly a reference to Shariah.

From Vatican, a local newspaper on its February 1, 2017 edition strongly criticized President Donald Trump's immigration policy. "Trump's recourse to walls and travel bans is counterproductive to America's economic interests," commented Archbishop Angelo Becciu, a top official in the Vatican's secretariat of state. "Certainly there's concern. Because we are messengers of another culture, that of opening, but also about the capacity of integrating those who arrive in our society and our culture," Becciu told TG2000, the television of the Italian bishops' conference.

Daily Independent in its January 30 edition wrote Donald Trump's ban on travellers from seven Moslem-majority nations could be just the beginning of a broader crackdown on moslim immigration, Amnesty International warned. Quoted an official of Amnesty International the daily issued an urgent call for Britain to do more to fight the policy, which effectively bans citizens from three African and four Middle Eastern countries from entering the US. It was accompanied by a 120 -day suspension of all US refugee program.

At home nearly all national newspapers - including daily Kompas, Koran Tempo, Media Indonesia, Republika, and Rakyat Merdeka -- blowed up and criticized Trump's Order. They feared the Order 
will have negative impact to Indonesia since we are a country with most moslim population in the world. In addition, tens of thousands of Indonesian are currently living in US.

Apparently there is no single government in the world which supports, explicitly or implicitly, President Trump's anti-immigrant policy, and no single media in Indonesia and elsewhere which does not criticize and condemn the policy. Koran Sindo might be the only newspaper in Indonesia which totally surprised any news regarding President Trump's travelban policy.

Daily Koran Sindo is a member of MNC Group, one of media conglomerations in Indonesia owned by Hary Tansoesoedibjo, a high profile business tycoon. He is in ownership of various mass media: print media (newspapers as well as magazines), television, online media, radio, social media, cable television, etc. Mr. Tanusoedibjo has close business cooperation with Donald Trump, a business tycoon-turned-to US President. Several business joint ventures between the two - Lido Lake Theme Park in Sukabumi, West Java and a luxurious hotel complex in Bali, among others, apparently, have been in realization. In September 2015 Hary facilitated a meeting between Speaker of Indonesian parliament, Setya Novanto dan Donald Trump in Trump Tower, New York. The meeting was also attended by Fadli Zon, Deputy Speaker of DPR. The meeting of Novanto and Trump caused heated reaction at home, especially media. Novanto and Fadli were accused of violating parliament code of ethics since Trump was campaigning his presidency against Hillary Clinton at the time. Parliament Honorary Council was promptly convened a meeting to investigate the case.

When campaigning his candidacy Trump stressed his commitment to ban people from several moslim countries in Arab and Africa to enter US, indirectly accusing them terrorists. Trump had no joke. $\mathrm{He}$ issued Executive Order soon after sworn-in as President. Strong criticism and resistance were coming worldwide, including US allies in Europe. Majority people in US echoed similar cynical attitudes: against Trump's anti-immigrant policy. US Court quickly questions whether President Trump's Executive Order is racial discriminatory in nature. Three judges at the appeals court in San Francisco have been charged with deliberating on whether a restraining order issued by a lower court should remain in effect while a challenge to the ban proceeds. Opponents of the ban argued that Mr. Trump's decision had "unleashed chaos" at airports in America and around the world, as thousands - including US green card holders - found themselves banned from boarding their planes to US or immediately detained upon arrival in US. They also argued that it was intentionally discriminatory against Moslems.

President Trump was upset when knowing his administration was not in full support for his Executive Order. The Justice department, fighting to lift the restraining order from Donald Trump's travel ban has made the first statements in the oral hearing at the San Francisco court of appeals. Attorney August Flentje, special counsel for the US justice department, argued that the suspension of the executive order had "upset the balance" that Mr. Trump had set when weighing up the options "welcoming people to this country" versus the risk of terrorism.

At home Indonesian government somewhat worried since thousands of Indonesians live in US. Foreign Minister of Indonesia had to issue a formal statement appealing our citizens in the States to calm down, and temporarily not to leave US. Similar statement was also issued by Minister of Religious Affairs. Practically all media in Indonesia gave strong coverage on the issue bearing in mind that Indonesia is a country with the greatest amount of Moslem population in the world.

Amazingly only Koran Sindo which totally censured the publication of stories about President Trump's policy on Travel ban and its heated reaction in US and worldwide. The paper also strictly avoided news whatsoever unfavorable to US new government under Trump presidency.

Three central questions or research questions, are formulated as followed: (1) How does daily Koran SINDO totally censure news on President Trump's anti-immigrant policy, especially regarding the banning of citizens of seven Arab and African countries -- with moslem majority population -- from entering US?; (2) What is the meta-meaning or motivation behind the total censure policy of daily Koran Sindo?; (3) As a nation which enjoys very much freedom of the press how is indeed the degree of journalist professionalism in Indonesia?

\section{Theoretical Framework}

Freedom of expression, notably freedom of the press, is one of the important pillar of democracy. Without press freedom a government cannot claim to 
be democratic. According to the 1977 Royal Commission on the Press, as quoted by Frost (2000), freedom of the press is "that degree of freedom from restraint which is essential to enable proprietors, editors and journalists to advance the public interest". Ofcom Broadcasting Code in Britain stressed that "Freedom of expression is at the heart of any democratic state. It is an essential right to hold opinions and receive and impart information and ideas." (Freedman, 2008). Kovach and Rosenstiel in their book entitled The Elements of Journalism (Rosenstiel \& Kovach, 2001) wrote that one of the principle or duty of the press: "Journalism must provide a forum for public to criticism and comment". News and report on important issues are presented to public so that the public could actively participate in discussing the issues. In democratic system the truth is in the hands of people, not the government. Truth evolves through active and continuous public discourses. The activity faces constraint if the public do not have ample input or information on important issues, issues which have public concern. The main source for such issues is undoubtedly media. The media, then, plays central role in democratic society. "This forum-creating capacity is so pervasive that it involves almost every aspect of the journalist's work, beginning with the initial report by which the journalist alerts the public to an event or condition in the community (Rosenstiel \& Kovach, 2001)".

According to Claude-Jean Bertrand, media play four important functions: (1) provide people with an image of the many aspects of the world that they cannot perceive themselves; (2) serve as a forum where big issues are debated until the needed consensus is reached; (3) teach the culture to all newcomers, children and immigrants, and (4) entertain their audience (a vital function in mass society).

When media censure or block an issue, intentionally or intentionally, the public does not aware of the issue and, consequently, lost opportunity to participate in its discourse while one of the central function of the media is to be a forum of public discourse to finally reach public consensus on any public issue. The public even might think the issue is non-existence if he or she is only exposed to one newspaper which happens blocks the story. Problem arises when the issue is, indeed, in their interest, too. The central question is who decides the publication of a story in the media.

In the early days of Libertarian Media Theory
(Siebert, Peterson, \& Schramm, 1956) it is the editors or journalist. In those days news is defined as "Anything that fits to print". It is the journalist who decides which is fit or not for a story to be printed. Arthur MacEwen, an American editor, defines news as "anything that makes a reader say, 'Gee Whiz'?". In essence, journalist can write and publish whatever he deems worth it. Censorship in those days have been abolished based on the idea of freedom of expression sponsored by Voltaire, Diderot, D'Alembert, Jefferson, and Madison (Jansen, 1988).

Media social responsibility theory, however, put a heavy stress on social responsibility. Press freedom is not absolute, but subject to social responsibility. Freedom can be temporarily ruled out when confronting with more serious national issue such as national security, and contempt of court. "If the reasons for covering it are morally, not just commercially, viable, or the moral reasons for using the story outweigh the moral arguments against, then we should publish (Frost, 2000)." Nowadays three sources are oftentime hampering freedom of the press: external physical pressure as the oldest constraint, internal moral pressure, and external moral pressure coming from peers and the public.

Theoretically, every journalist should work professionally since he or she is a professional. The major guidance for printing or not printing news is public concern. Nevertheless, newsworthiness, objectivity, the space available, and fairness, of course, influence editors in their decisions on what to publish (Frost, 2000). According to Merrill (in (Callahan, 1988)) journalists like to think of themselves as "professionals" and journalism as a "profession". Bernard Barber as quoted by Merrill wrote that professional behavior may be defined in terms of four essential attributes: (1) a high degree of generalized and systematic knowledge, (2) a primary of orientation to the community interest rather than individual self-interest; (3) a high degree of group control of behavior through codes of ethics and through associations organized and operated by themselves and (4) a system of rewards (monetary and honorary) for those who conduct the work.

According to Lynn in his introductory section to Callahan's book (1988), a professional is never hired. "He is retained, engaged, consulted by someone who needs his services. The professional has, or should have, almost complete control over what he does for his client". If a journalist bowed to his boss, owner of the media he serves regarding the media content, he 
is definitely not a professional, but an employee.

Journalist in Indonesia is acknowledged as professional as well. Bill number 40/1999 on The Press explicitly stated the professionalism of Indonesian press. Since the past three years Indonesian Journalists Association and Press Council are consistently conducting training to journalists across the country. By the end 2017 whoever claims to be journalist must be able to show his "press certificate" issued by the Press Council. They are obliged to honor and implement Journalist Code of Ethics chartered by Press Council. Punishment by the Council will be inflicted to journalist who does not abide by the Code when doing his journalistic work. Undoubtedly, Indonesia Press Council is continuously monitoring media and journalist behavior. The Council is also actively response to any complain coming from public regarding journalist's deviant behavior

But Marxist media theory followers unanimously acclaim that freedom of the press in capitalist nations are completely false. It is the media owners who enjoy freedom of the press, not the journalists. Editors and journalists are no less than employee who are subject to owner's interest. Even chief editor could be anytime be kicked off by the owner when he or she does not follow owner's policy or interest in the editorial desk.

Journalist freedom is, indeed, hampered especially by media owner as stated by McChesney (2015). "Professional journalism was predicated on the notion that its content should not be shaped by the dictates of owners and advertisers, or by the biases of the editors and reporters, but rather by core public service values. "Ho Loksang, a Hong Kong based journalist, writes that government interference in the media in Hong Kong is non-existent, but commercial and personal influence on it is unavoidable. "One of the concerns expressed by the public is possible intervention by the owners of media over reporting. Owners run news media for a reason. If they decide that a commentary or a news report goes against their beliefs or their interests or if they consider them biased, they certainly will want to intervene."

Some lecturers at Department of Mass Communication, Elizade Universiy, Ilara-Mokin Ondo State, Nigeria, based on their extensive research on African press freedom remind us a well-known jargon in journalism "He who pays the piper calls the tune". Ownership has continued to play an influential role in the editorial policies of media organizations. It is so bad in some media organizations that the ethics of journalism are exchanged with the opinions and decisions of the proprietors of the organization. They quoted McQuail that "There is no doubt that owners in market based media have ultimate power over content and can ask for what they want to be included or left" though this is against journalism ethics.

The case of daily Koran Sindo, the object of my inquiry, questions the professionalism of its journalists and editors in deciding news worthiness. The fact that the paper totally suppresses all stories regarding President's Trump travel policy is a clear indication that its editors totally subject to the owner's power even though Sindo's editors very well aware of news values of the issue. "Impact" and "Relevance" [to our community] are agreed among journalists as the most important news values in writing a story. "Will the information in this story change our lives or have great impact to our nation". "Is it relevant or not to our community or nation?” (Norman, 2014).

Stories about US President's travel ban policy is clear very relevant to Indonesian public, even has impact to us. First, Indonesia is Moslem most populous nation in the world. Second, terrorism is currently the most serious threat to our nation; third, more than hundred thousand Indonesian are living in US, and fourth, our government has long been in good relations with Arab nations.

\section{Material and Methodology}

The current research is qualitative in nature, since I am only interested in the meaning of narratives or texts carried out by the mass media, i.e. newspaper (Berger, 2015). A simple qualitative content analysis is applied. Semiotics method is used to make sense of "signs" which is content of text (news). Semiotics is for sensory meaning, i.e. meaning created, in our research, through visual image which is texture.

News on President's Donald Trump's Executive Order on Travel Ban policy - 23 items at daily Koran Sindo, 8 at Media Indonesia and 11 at Kompas were thoroughly investigated. Berger (2015) is of the opinion that "Many aticles in newspapers and magazines are semiotic in nature in that they attempt to make sense of various objects and phenomena that semioticians would call 'signs'”. The stories inquired were published from January 31, 2017 to February 7, 2017. January 31, 2017 is selected as cut-off date since 
Trump's Executive Order was issued on January 27, 2017.

Focus of inquiry is daily Sindo; how Sindo articulates news about Trump's policy. Media Indonesia and Kompas are chosen arbitrarily for comparison purpose. While Media Indonesia is owned by Surya Paloh, Chairman of Democratic National Party (Nasdem), one of the strongest supporter of Jokowi administration, Kompas is widely acknowledged as the number one national daily in Indonesia, reputed for its independent and objective reporting.

A total of 42 news items are analyzed according to the following procedure: (1) Critical attention is focused on the headline of the news and the leads: Is it in favor or critical against Trump's travel-ban policy?; (2) Analyze the news content: What are the key words of the stories? What are the meta-meaning behind the key words used?; (3) How does the journalist/editor draft his conclusion on the stories about Trump's travel-ban policy? Critical, neutral, or leave it to the readers to draw their conclusion?

Final comparison is drafted in a table to get a clear picture how the three newspapers construct news on President Trump's Executive Order on Travel Ban. A hypothetical conclusion is drawn on Sindo motivation to totally censure news about President Trump's travel-ban policy.

\section{Result and Discussion}

Out of 23 stories published on International Page of daily Koran Sindo dated January 31, 2017 to 7 February 2017, none is about President Trump's controversial travel-ban policy as shown in Table 1.

The paper purportedly censured all news about the issue. Instead it raises stories as its headline of International Page with less degree of news values, i.e. "Impacts" and "Prominence". Some items of the stories published on its "International Page" in the period of inquiry are: (1) "Socialist President (of France) candidate promised labor pay raise" (2) "The Philippines crushes corrupt policeman"; (3) "Thousands of people attended funeral ceremony of Myanmar lawyer"; (4) "US Defense Minister visits to Asia"; (5) "Hillary Clinton writes a book of essays"; (6) "Snow blizzard hit Afghanistan and Pakistan"; (7) "Myanmar military and police chiefs are subject to punishment"; (8) "Louvre reopened after terrorist attack"; (9) "France persuaded to quit European Union"; (10) "Chinese ship sailed to dispute island"

Sindo exhibits three to five stories on its "Inter- national Page" every day. All the news inquired in the period of January 31, 2017 to 7 February 2017 had nothing related to President's Trump Executive Order and world reactions.

Media Indonesia and Kompas as shown in Table 2, however, put the stories on Trump's travel-ban policy in headline format with so many words criticizing, even, condemning the policy. Out of 8 news related to US travel ban issue at daily Media Indonesia, all are very critical in nature. Resistances within US inner circle against the policy is strongly exposed at Media Indonesia. Similar attitude is echoed by daily Kompas. Using strong language and eye-catching headline Kompas reflects its outrageous stand against Trump discriminatory policy.

Following are the key words found at the news regarding Trump's anti-immigrant policy published at the two dailies, each with their meta-meaning:

All news about Trump's Executive Order published at daily Media Indonesia and Kompas are criti$\mathrm{cal}$ in nature. Some of the two papers were published as headline stories. Opinions of several world leaders, such as UN Secretary General, German Chancellor, Britain Prime Minister, Iranian supreme spiritual leader and former US President, Obama, were exposed to strengthen world stand on the issue. The two papers implicitly drag the readers to have the same opinion that the Trump's policy is, indeed, discriminatory, anti-Islam and unconstitutional. Sindo, however, completely blocks the story. The paper instead publishes miscellaneous stories worldwide, some of them even have no primary news values.

Back to 1951 Israeli Prime Minister, David BenGurion, involved a hot debate with Menachem Begin (a young MP at the time) in Knesset. Topic of debate is about who really a journalist is. "What is a newspaper?" asked Ben-Gurion, and he prompted responded himself: "A person who has money hires workers who writes what he wants them to write" (Rosenfeld, 1993). Ben-Gurion statement elicited strong criticism among journalists who attended the debate in Knesset. But a journalist from Ben-Gurion perspective, no less than an employee who must ardently serve his master, media owner.

Over 40 years later a journalist of the Jerusalem Post, Joanna Yehiel, sued the paper for firing her. Interference of paper's owner in the case was strongly suspected. The issue revealed by Prime Minister BenGurion, "Is a journalist like any other employee?" reemerged. Judge Elisheva Barak in the proceeding 
Table 1. Matrix of Contents of three Newspapers on President Trump's Travel-ban Policy at Koran Sindo, Media Indonesia, and Kompas, January 31, 2017 - February 8, 2017

\begin{tabular}{|c|c|c|c|}
\hline Date & Koran SINDO & Media Indonesia & Kompas \\
\hline $31 / 01 / 2017$ & $\begin{array}{l}\text { a. "Capres Sosialis Janjikan } \\
\text { Kenaikan Gaji pada Pemilihan } \\
\text { Umum Pendahuluan di Perancis". } \\
\text { b. "Filipina Berantas Polisi Korup" } \\
\text { c. Ratusan Ribu Pelayat Hadiri } \\
\text { Pemakaman Pengacara } \\
\text { Myanmar". } \\
\text { d. Mantan Milyader Eike Batista } \\
\text { Kembali ke Brasil untuk Diadili". } \\
\text { (Out of four news published at } \\
\text { Sindo International page, none } \\
\text { was about President Trump's } \\
\text { Executive Order banning people } \\
\text { from } 7 \text { Arab and African countries } \\
\text { to enter US). }\end{array}$ & $\begin{array}{l}\text { "Penembakan Masjid Kanada } \\
\text { Dampak Kebijakan AS" } \\
\text { (Bomb blast in Quebec } \\
\text { is thedirect impact of US } \\
\text { administration policy to ban } \\
\text { people from } 6 \text { middle east and } \\
\text { African countries to enter US, } \\
\text { according to Media Indonesia } \\
\text { sources. The headline news } \\
\text { on page } 13 \text { is the paper strong } \\
\text { condemnation against Trump's } \\
\text { immigration policy). }\end{array}$ & $\begin{array}{l}\text { a. "Kebijakan Kontroversial Trump Memaksa Obama } \\
\text { Berbicara" } \\
\text { (For the first time ever since his step down as US President } \\
\text { Barrack Obama made a comment on his predecessor's } \\
\text { controversial policy. Obama was moved to response the } \\
\text { travel -ban issue. He strongly critized Trump's Executive } \\
\text { Order. "It is people constitutional right to assemble and } \\
\text { echoed their concern and the leader should listen deeply } \\
\text { their voice," said former President Obama). } \\
\text { b. "Menteri Agama Minta Warga Indonesia Tak Reaktif soal } \\
\text { Kebijakan Trump" } \\
\text { (Minister of Religion Affairs, Lukman Hakim Saifuddin, } \\
\text { tried to calm down Indonesia citizens living in US regarding } \\
\text { Trump Moslem Ban Issue. "We should not over-reacted } \\
\text { policy made by our neighbor friendly countries," said the } \\
\text { Minister. "Our president and Foreign Minister always in } \\
\text { proactive position in response to global situation.") } \\
\text { c. "Akibat Kebijakan Trump, } 6 \text { Warga Iran Terdampar di } \\
\text { Belanda" } \\
\text { (Six Iranian leaving for US were compelled to stay for } 3 \\
\text { nights at Schipol airport, Amsterdam. The incident was due } \\
\text { to President's Executive Order which ban people from } 7 \\
\text { Arab countries - including Iran - to enter America. "When } \\
\text { we left Teheran nobody told us about US new travel ban. } \\
\text { They gave us boarding pass, everything seemed OK," said } \\
\text { one of them to the press). } \\
\text { d. "Trump Pecat Jaksa Agung Penentang 'Moslem Ban" } \\
\text { (Sally Yates, Obama appointed Attorney General, was } \\
\text { fired by President Donald Trump. The President was very } \\
\text { upset because Yates instructed to all judges in the Justice } \\
\text { Ministry not to obey Trump's travel-ban order). }\end{array}$ \\
\hline $1 / 02 / 2017$ & $\begin{array}{l}\text { a. "Tersangka Terror Quebec } \\
\text { Didakwa". } \\
\text { (SINDO blows up news on the } \\
\text { progress of Quebec terrorism } \\
\text { suspect trial in Canada. Bloody } \\
\text { incident in Quebec is portrayed } \\
\text { as a separate issue unrelated at } \\
\text { all with Trump's anti-immigrant } \\
\text { policy). } \\
\text { b. "Dewan Keamanan PBB Bahas } \\
\text { tes Rudal Iran" } \\
\text { c. "Pembunuhan Pengacara } \\
\text { Bertujuan Kacaukan Myanmar". }\end{array}$ & $\begin{array}{l}\text { "Trump Pecat Jaksa Agung" } \\
\text { (President Trump were upset } \\
\text { with his Attorney General, Sally } \\
\text { Yates, for her disobedience to } \\
\text { implement the President's Order } \\
\text { on immigration policy. It is a long } \\
\text { story, describing Trump's strong } \\
\text { warning that he is more than } \\
\text { ready to fire any of his staff who } \\
\text { does not carry out his order). }\end{array}$ & $\begin{array}{l}\text { a. "PM Inggris: Kebijakan Donald Trump Keliru" } \\
\text { (British Prime Minister, Theresa May, strongly criticized } \\
\text { Trump anti-immigrant policy. "Our government is clearly of } \\
\text { the opinion that the policy is completely erroneous," said } \\
\text { May. "It is wrong and has potentiality to break up global } \\
\text { unity. "Great Britain is a traditional European ally of US). } \\
\text { b. "Sekjen PBB Bersuara: Minta Trump Segera Cabut } \\
\text { Kebijalkan Anti-imigran". } \\
\text { (In a strong message directly sent to President Trump, UN } \\
\text { Secretary General, Antonio Guterres, criticized President } \\
\text { Trump's anti-immigration policy. He urged Trump to } \\
\text { immediately revoked the policy. Guterres believed that the } \\
\text { Trump's policy is not based on valid intelligence finding, and } \\
\text { accordingly will not be effective). }\end{array}$ \\
\hline \multirow[t]{2}{*}{$2 / 02 / 2017$} & $\begin{array}{l}\text { a. Page } 13 \text { headline: "Menhan AS } \\
\text { melawat ke Asia". } \\
\text { (It is about the visit of US Defense } \\
\text { Minister to several Asian nations, } \\
\text { including Indonesia). }\end{array}$ & $\begin{array}{l}\text { "Diplomat AS Tolak Perintah } \\
\text { Trump" } \\
\text { (About } 900 \text { US diplomats, in } \\
\text { a joint statement, rejected } \\
\text { President Trump's Moslem } \\
\text { Ban policy. All the diplomats } \\
\text { put their signatures in a written } \\
\text { statement. "US will not be } \\
\text { saver because of the ban," the } \\
\text { statement said). }\end{array}$ & $\begin{array}{l}\text { "Keputusan Trump Digugat" } \\
\text { (President's Executive Order was beginning examined by } \\
\text { State Supreme Court. The court acted upon people's mass } \\
\text { petition). }\end{array}$ \\
\hline & $\begin{array}{l}\text { b. "Teror Quebec: "Pelaku sewa } \\
\text { apartemen dekat Masjid". } \\
\text { (Koran SINDO seemingly happy } \\
\text { with Canadian police investigation } \\
\text { progress on the Quebec mosque } \\
\text { terrorist attack. The attack was } \\
\text { considered in line with President } \\
\text { Trump policy to ban moslim } \\
\text { people from entering US). } \\
\text { c. "80 Elang Terbang dengan } \\
\text { Pesawat Boeing" } \\
\text { d. "Uni Eropa dan ASEAN Beri } \\
\text { Beasiswa" }\end{array}$ & & \\
\hline
\end{tabular}




\begin{tabular}{|c|c|c|c|}
\hline Date & Koran Sindo & Media Indonesia & Kompas \\
\hline $3 / 02 / 2017$ & $\begin{array}{l}\text { a. Page } 13 \text { headline: "Perkuat } \\
\text { aliansi Merkel Temui Erdogen". } \\
\text { (German Chancellor, Merker, } \\
\text { visited Ankara and talked with } \\
\text { President Erdogen of Turkey. They } \\
\text { exchanged view on strengthening } \\
\text { the bilateral relations. The two } \\
\text { leaders discussed various issues, } \\
\text { including global terrorism. But no } \\
\text { mention was made on President } \\
\text { Trump banning people from } 6 \text { Arab } \\
\text { countries to enter US). } \\
\text { b. Hillary Clinton Menulis Buku } \\
\text { Esai" } \\
\text { c. "Migrasi dari Afrika ke Eropa } \\
\text { akan Meningkat" } \\
\text { (No mention at all issue of Trump's } \\
\text { controversial policy on immigration. } \\
\text { The news is only forecasts the } \\
\text { speculation on the possibility of } \\
\text { rising immigrant outflow from Africa } \\
\text { to Erirope). } \\
\text { d. "Korsel - AS Tingkatkan Sistem } \\
\text { Pertahanan Rudal". } \\
\text { (US Defense Minister visited South } \\
\text { Korea and met with Korean Prime } \\
\text { Minister, Hwang Kyo-khu. Topic } \\
\text { discussed, among others, about } \\
\text { the strengthening of defense } \\
\text { cooperation). }\end{array}$ & $\begin{array}{l}\text { "Trump naik pitam bahas } \\
\text { kesepakatan imigran" } \\
\text { (In a cabinet meeting President } \\
\text { Trump again echoed his stern policy } \\
\text { to ban people from } 7 \text { Arab and } \\
\text { African nations which are majority } \\
\text { Moslems to enter US). }\end{array}$ & $\begin{array}{l}\text { "Pentagon Umumkan Pengecualian Terkait } \\
\text { Kebijakan Anti-Imigran Trump" } \\
\text { (In an official statement Thursday Pentagon said } \\
\text { exception was made on the implementation of } \\
\text { Moslem-ban policy. Those in the } 7 \text { Arab countries } \\
\text { who assisted US military in the past were allowed } \\
\text { to enter US). }\end{array}$ \\
\hline $6 / 02 / 2017$ & $\begin{array}{l}\text { a. "AS Ingin akhiri konflik Ukraina". } \\
\text { b. "Pujian Trump pada Presiden } \\
\text { Putin". } \\
\text { (Koran SINDO raised the issue } \\
\text { which is in fact has no significance } \\
\text { to Indonesia in its "International" } \\
\text { page). } \\
\text { c. "Badai Salju Terjang Afghanistan } \\
\text { dan Pakistan". } \\
\text { d. "Louvre Kembali dibuka setelah } \\
\text { Aksi Teror". }\end{array}$ & $\begin{array}{l}\text { a. "Boikot Momok di Era Trump" } \\
\text { (Donald Trump's Executive Order } \\
\text { has caused frictions among } \\
\text { business realm in America. A } \\
\text { number of retail corporates took } \\
\text { precaution in selling their products, } \\
\text { fearing boycott from the consumers } \\
\text { who were anti-Trump "Anti- } \\
\text { immigrant" policy). } \\
\text { b. "Dikejar Waktu Menuju Amerika" } \\
\text { (People from } 7 \text { Arab and African } \\
\text { target of Trump's anti-immigrant } \\
\text { policy were happy hearing Seattle } \\
\text { federal judge decision to suspend } \\
\text { the implementation of President } \\
\text { Trump's anti-Moslem policy. The } \\
\text { joy, however, apparently was just for } \\
\text { a short moment since the Office of } \\
\text { Attorney General quickly submitted } \\
\text { appeal to the higher court). } \\
\text { c. "Pengadilan AS Tolak Banding } \\
\text { Trump" (h. 2) } \\
\text { (US Federal appeal court turned } \\
\text { down President Trump's appeal for } \\
\text { his Executive Order implementation. } \\
\text { The decision made the Order dated } \\
\text { January 27, } 2017 \text { adjourned until } \\
\text { US Supreme Court final verdict). }\end{array}$ & $\begin{array}{l}\text { "Masa Pro-Trump dan Anti-Trump Berhadap- } \\
\text { hadapan di Luar Trump Tower" } \\
\text { (Hundreds of people - those who are pro-Trump } \\
\text { and anti-Trump - involved in a face-to-face mass } \\
\text { action near to Trump Tower, New York. The central } \\
\text { issue at stake was President Trump's Moslem Ban } \\
\text { policy. The rally was also marked by "banner wars". } \\
\text { "Welcome the Trump Era", a banner of pro-Trump } \\
\text { wrote. On the other side a huge banner was hang: } \\
\text { "No ban, no wall, refugees are welcome here"). }\end{array}$ \\
\hline $7 / 02 / 2017$ & $\begin{array}{l}\text { a. "Kapal China Berlayar Dekat } \\
\text { Pulau Sengketa. } \\
\text { b. "Para Komandan Militer dan } \\
\text { Polisi Myanmar } \\
\text { c. "Harus Dihukum" } \\
\text { d. "Jepang Bangun Hotel untuk Kutu } \\
\text { Buku". } \\
\text { e. "Ajak Perancis keluar dari Uni } \\
\text { Eropa". }\end{array}$ & $\begin{array}{l}\text { "Trump Kecam Pengadilan AS" } \\
\text { (President Trump was upset on } \\
\text { federal judge verdict to delay } \\
\text { his policy on anti-immigrant, } \\
\text { and immediately expressed his } \\
\text { determination to send appeal to the } \\
\text { Supreme Court). }\end{array}$ & $\begin{array}{l}\text { a. "WNA Mulai Masuk Amerika" } \\
\text { b. "Ayatullah Ali Khamenei: Trump Ungkap Wajah } \\
\text { Asli Amerika". } \\
\text { (Iranian supreme spiritual leader, Ayatullah Ali } \\
\text { Khamenei, strongly condemned President Trump's } \\
\text { anti-immigrant policy. Commenting on Iranian } \\
5 \text { year child handcuffed at one of US airport, } \\
\text { Khamenei questioned US respect on human rights. } \\
\text { The tragic incident at the US airport, according to } \\
\text { Khamenei, signified how US government harassed } \\
\text { the human rights). }\end{array}$ \\
\hline
\end{tabular}


Table 2. News key words and their meta-meaning

(Kompas, and Media Indonesia, January 31, 2017 - February 7, 2017)

\begin{tabular}{|c|c|c|}
\hline Dailies & $\begin{array}{l}\text { Signifier } \\
\text { (keywords in the story) }\end{array}$ & $\begin{array}{l}\text { Signified } \\
\text { (Meta-meaning) }\end{array}$ \\
\hline \multicolumn{3}{|c|}{ Media Indonesia } \\
\hline $31 / 01 / 2017$ & $\begin{array}{l}\text { Serangan teroris di masjid akibat kebijakan } \\
\text { Trump }\end{array}$ & Terrorist act is directly correlated with Trump's policy \\
\hline $1 / 02 / 2017$ & Jaksa Agung menentang Trump & Even Attorney General rejects Trump \\
\hline $2 / 02 / 2017$ & Diplomat AS tolak perintah Trump & US diplomats against Trump's policy \\
\hline $3 / 02 / 2017$ & $\begin{array}{l}\text { Trump naik pitam (karena perintahnya tidak } \\
\text { dilaksanakan) }\end{array}$ & Strong resistance against Trump. \\
\hline \multirow[t]{2}{*}{$6 / 02 / 2017$} & a. Boikot, momok & a. Trump's policy is sort of evil. \\
\hline & $\begin{array}{l}\text { b. Melanggar kebebasan beragama, tidak } \\
\text { sesuai dengan konstitusi }\end{array}$ & b. The policy is against freedom of the press. \\
\hline \multirow[t]{2}{*}{$7 / 02 / 2017$} & a. Mengecam putusan pengadilan, & a. Trump very angry losing battle in court \\
\hline & b. Pendukung dan penentang turun ke jalan & b. The travel-ban policy elicit social horizontal conflict \\
\hline \multicolumn{3}{|l|}{ Kompas } \\
\hline \multirow[t]{4}{*}{$31 / 01 / 2017$} & a. Memaksa Obama untuk bicara & $\begin{array}{l}\text { a. Obama loses patience not to criticize his } \\
\text { Predecessor }\end{array}$ \\
\hline & b. Tidak terlalu reaktif & $\begin{array}{l}\text { b. The minister tries to cool down our citizens living } \\
\text { in US. }\end{array}$ \\
\hline & c. Harus menjalani pemeriksaan & $\begin{array}{l}\text { c. Iranians are compelled to proceed immigration } \\
\text { clearance though they already hold US visas }\end{array}$ \\
\hline & d. Sally Yates mengkhianati & d. Attorney General is a traitor \\
\hline \multirow[t]{2}{*}{$1 / 02 / 2017$} & a. Jaksa Agung menentang AS & a. Strong criticism against Trump \\
\hline & b. Mencabut, penilaian buta & b. UN Sect. General condemns Trump; \\
\hline $2 / 02 / 2017$ & Pelanggaran konstitusi,menggugat & Judges and lawyers against Trump's policy \\
\hline $3 / 02 / 2017$ & Pengecualian, mendapat pertimbangan khusus & $\begin{array}{l}\text { White House softens its stand due to criticism from } \\
\text { abroad and at home }\end{array}$ \\
\hline $6 / 02 / 2017$ & Massa berhadap-hadapan & $\begin{array}{l}\text { Trump policy elicits physical conflict between } \\
\text { supporters of the two blocks }\end{array}$ \\
\hline \multirow[t]{2}{*}{$7 / 02 / 2017$} & $\begin{array}{l}\text { a. WNA berdatangan ke AS (setelah ada } \\
\text { perintah penundaan kebijakan Trump; Trump } \\
\text { salahkan pengadilan }\end{array}$ & $\begin{array}{l}\text { a. Trump fights back, but court verdict is good news } \\
\text { for those nations }\end{array}$ \\
\hline & $\begin{array}{l}\text { b. Menunjukkan arti sesungguhnya HAM bagi } \\
\text { pemerintah Amerika }\end{array}$ & b. US really humiliates human rights \\
\hline
\end{tabular}


court issued a critical statement: "The owners and publishers are protected by the basic right of freedom of expression, but that this right is balanced by the right of editors and journalists to freedom of the press and to the expression of their own opinions".

Judge Barak seemingly warns media owner that the power he enjoys cannot be arbitrarily exercised. His freedom of expression is subject to honoring freedom of expression of his editors, too. He cannot exhibit absolute authority in running the media, including determining media content and firing every single journalist who does not comply with his commercial interest. Media owner must bear in mind that journalist is a professional, not a worker or employee. Being a professional, a journalist, especially an editor, is trained to always uphold truth, honesty and justice when performing his tasks, above all defining news worthiness.

Back to about 30 years ago a child was dragged by waves and found dead at Bina Ria Beach, Taman Impian Jaya Ancol (TIJA). The beach was popular destination for family recreation, especially on Sundays. Hundreds of people, mostly children, were packed at the beach. A reporter of Tempo magazine, coincidentally, learned about this incident and wrote an article about it. As his draft was submitted for review, the editorial supervisor decided to hold back publishing this story. Instead he consulted with the editor in chief knowing that Ciputra, the largest stakeholder of Tempo magazine, was also the President Commissioner of TIJA. When Goenawan Mohammad as editor in chief of Tempo magazine informed Ciputra, he was immediately asked to kill the story. A heated conversation took place over the phone as Goenawan persisted in convincing Ciputra that the story was worth publishing as a warning to management of TIJA to enforce safety measures on this popular family oriented beach. Finally, Ciputra agreed to have the article printed even though he had concerns such news could impact the positive image of Bina Ria beach.

Two such examples demonstrate that media owners at times intervene in newsroom. Such action could end up being successful but quite often receives pushback from editor in chief.

When Rupert Murdoch's BskyB in November 2006 bought nearly $18 \%$ of Britain largest commercial terrestrial broadcaster, ITV, media community in Britain promptly condemned the move. A popular film producer, David Puttnam, argued that what was at stake was (a) the erosion of competition within the
British media, and (b) British democracy. According to Des Freedman (2008), "The idea that Rupert Murdoch is a threat to democracy rests on the notion that media ownership matters and that, where it is concentrated, it represents an unacceptable challenger to pluralist principle of a diverse and competitive media system".

Media ownership, undoubtedly, matters on freedom of the press even in the West. Media conglomeration in the hand of one or view owners is tantamount to fully control the newsroom, thereby restricting editor freedom in deciding media content. Intervention in newsroom is a matter of seriousness to Indonesia journalists, as well. Indonesia press freedom index 2015 has clearly stressed the issue. "Journalist professionalism and media healthy management must be uphold. Media should keep its independency and media newsroom must be freed from any self-interest and intervention," Yosep Adi Prasetyo, Head of Indonesia Press Council assuredly responded to Indonesian press community deep concern over media owner's intervention in the newsroom (Kompas, 2010-2015). Adi's statement, implicitly, acknowledges owners widespread interference in our press.

Regarding Koran Sindo policy to completely block stories of President Trump's travel-ban order, Hary Tanoesoedibjo close personal relationship with Donald Trump is definitely the main factor. Moreover, Mr. Tanoe is pursuing business joint-venture in Indonesia with Trump corporations. He might be very worried that exposure and critique of Trump's unpopular anti-immigrant policy in his media will spoil his personal and business relation.

\section{Conclusion}

Supporters of libertarian media theory believe that the media plays central role in upholding democratic system. Through media people actively participate in public discourse which is one of the critical pillar of democracy. The media must provide themselves as forum of public discourse and deliberation. Press freedom is a sine qua non condition for this purpose.

Press freedom in Indonesia since the past ten years, however, faces serious obstacles. Interference of media owner in newsroom is considered one of the most serious obstacles. Motivation for owner's intervention could be numerous. Business and political interest, among others. If the owner perceives a news report or commentary goes against his beliefs or in- 
terests, his intervention might be unavoidable.

In such a case, press freedom is, undoubtedly, the prime victim.

According to McChesney (2015), the media nowadays "has become significant anti-democratic force in United States and, to varying degree, worldwide. The wealthier and powerful the corporate media giants have become, the poorer the prospect for participatory democracy. (McChesney, 2015). In his widely read book, "Censorship. The Knot that Binds Power and Knowledge", Jansen (1988) stressed "The free market of ideas has been replaced under corporate capitalism in world forum as freedom of multinational corporations from restriction in the proper conduct of their business." American philosopher, writer, and educator, Susanne Katherina Langer as quoted by Jansen (1988) described the power to name as the vastest generative idea that ever was conceived. "The powerful use this power to generate and enforce definition of words and of social reality that enhance their sovereignty".

In the context of press freedom, the powerful (owner of media), then, reserves the right to generate and enforce definition of news and of social reality. Applying Langer's logic, Hary Tanoesudibdjo's supposed interference in defining story about President Donald Trump's travel-ban policy is a matter of reasonable thinking, minding that he is the most powerful man in MMC group in which daily Koran Sindo is part of it. But freedom of the press is seriously threatened if newsroom policy can be anytime intervened by media owner as emphasized by Indonesian Press Council.

We are fully agreed with Indonesian Press Council standpoint. It is very tragic if story with great magnitude and importance such as President Trump' controversial discriminatory policy is totally censured by a newspaper. A murky portrait of freedom of the press has been clearly painted by the case of $\mathrm{Ko}$ ran Sindo. Journalist in Indonesia is apparently still reckoned as an employee, not professional, at least by owner of the media.

\section{References}

Berger, A. A. (2015). Media and communication research methods: An introduction to qualitative and quantitative approaches. Sage Publications.

Callahan, J. C. (1988). Ethical issues in professional life. Oxford University Press.

Freedman, D. (2008). The politics of media policy. Polity. Frost, C. (2000). Media ethics and self-regulation.

Jansen, S. C. (1988). Censorship: The knot that binds power and knowledge. Oxford University Press.

McChesney, R. W. (2015). Rich media, poor democracy: Communication politics in dubious times. New Press, The.

Norman, B. (2014). How to judge the news value of your paper. Retrieved from https://hub.wiley.com/ community/exchanges/discover/blog/2014/05/22/ how-to-judge-the-news-value-of-your-paper

Rosenfeld, S. (1993). Is a journalist like any other employee? רשק, 2e--5e.

Rosenstiel, T., \& Kovach, B. (2001). The elements of journalism. New York: Crown.

Siebert, F. S., Peterson, T., \& Schramm, W. (1956). Four theories of the press: The authoritarian, libertarian, social responsibility, and Soviet communist concepts of what the press should be and do. University of Illinois Press. 